Research Article

\title{
Study of macro algae as marine biomass energy source
}

\begin{abstract}
Algae are organisms that grow in aquatic environments using the light and carbon dioxide $\left(\mathrm{CO}_{2}\right)$ to create biomass. Macro algae are larger algae that can grow in a variety of ways. Algae can be explored for a variety of other uses such as biofuels, fertilizer and pollution control. In addition, algae can also be used for reducing the emissions of $\mathrm{CO}_{2}$ from power plants. $\mathrm{CO}_{2}$ produced by the power plant could be utilized as a carbon source for algal growth, and the carbon emissions would be reduced by recycling waste $\mathrm{CO}_{2}$ from power plants into clean-burning biodiesel.
\end{abstract}

Keywords: Algae, Energy Sources, Biodiesel
Volume 2 Issue I - 2015

\author{
O Oladokun Sulaiman, A Saman Abd Kader, \\ SAzman \\ Maritime Technology, Malaysia
}

Correspondence: $\bigcirc$ Oladokun Sulaiman, Maritime Technology, Malaysia,Tel+60177244339, Email odokun2003@yahoo.com

Received: October 12, 2014 | Published: January 07, 2015

\section{Introduction}

Biomass production from macro algae has been viewed as important mainly because of the need for pollution abatement and energy source. Environmental considerations will increasingly determine use of macro algae product and improve process acceptability that drive the next generation of economic opportunity. In context, biomass refers to any source of heat energy that is produced from non-fossils biological materials. Unlike fossil fuels, biomass is a renewable energy resource that is available where the climatic conditions are favorable for plant growth and production. Biomass is considered as an attractive alternative to fossil fuels as a source of energy. In addition to this, the biomass can also be used for carbon capture. The carbon capture is an approach to mitigate the global warming by capturing the carbon dioxide from the large point sources such as fossil fuel power plants and storing it instead of releasing it into atmosphere like technology for large scale capture of $\mathrm{CO}_{2}$ is already commercially available and fairly well developed. ${ }^{1}$ The different macro algae survive in different habitat. Thus, study focus on the types of macro algae which are suitable cultivation in Malaysia water. This approach would identify the oceanic parameters that are most suitable for the macro algae and conduct species matching. ${ }^{2}$

\section{Need for Alternative Oil Source}

There are several problems associated with the energy use in this country. First of all, there is requirement to overcome future possible oil shortage. The reservoirs are about 2000 billion tones whereas the daily is using about 71.7 million tons. ${ }^{3}$ Besides, there is need to reduce the impact of global warming and climate change. The increasing of greenhouse gas emission such as carbon dioxide caused bad impact to the country. Based on estimation in 2000, more than 20 metric tons of carbon dioxide was release to the atmosphere every year. ${ }^{4}$ The macro algae cultivation can reduces the released of greenhouse gas from the energy production. Through, application of macro algae as the marine biomass energy sources, the net emission of carbon into atmosphere from carbon capture may reduce.

\section{Methodology}

\section{Water Sampling}

The water samples were takes in Setiu Wetland, Bidong Island and Perhentian Island. The 200 meter depth is marks on the rope at the vandorn water sampler. The latitude and longitude at the location was identified using the Global Positioning System (GPS). The GPS was set up assuming 500 meter distance from the shore. The water samples are transfer immediately into bottles after takes using vandorn water sampler to prevent the disruption of surrounding. The most suitable for macro algae survive is about $29-32 \mathrm{oC}$.

Setiu Wetland: Two different times are taken which is at $11.00 \mathrm{am}$ and $3.00 \mathrm{pm}$. So, four different of water samples are taken. The location of Setiu wetland are N 05o 40.540' E102o 43.080' and N 05o 40.313 E 102o 43.934'. Temperature of water samples was taken a moment after exchange the samples into the bottles. The water temperature is $32 \mathrm{oC}$. This figure show the location of Setiu Wetland where the water samples are taken (Figure 1).

Bidong Island: Bidong Island is one square kilometer in area and accessible from the coastal town of Merang. It is located at 05036 $\mathrm{N}$ and 103o $03 \mathrm{E}$. At the Bidong island also takes two times samples, in $11.00 \mathrm{am}$ and $3.00 \mathrm{pm}$. Four collected of water samples taken and the temperature were identified. It is located $05036.828 \mathrm{~N}$ and $103 \mathrm{o} 03.262 \mathrm{E}$. The water temperature is $31 \mathrm{oC}$. This figure show the location of Bidong Island where the water samples are taken (Figure 2).

Perhentian Island: Perhentian Island is divided by two which is Perhentian Kecil and Perhentian Besar. The sampling site is at Perhentian Kecil with located at $05051 \mathrm{~N}$ and 102044 E. Two different times are taken which is at $3.00 \mathrm{pm}$ and $10.00 \mathrm{am}$ on the next day. ${ }^{5,6}$ The location of Perhentian Island is $05021.26 \mathrm{~N}$ and 102044.2 $\mathrm{E}$ and the water temperature is $29 \mathrm{oC}$. This figure show the location of Bidong Island where the water samples are taken (Figure 3).

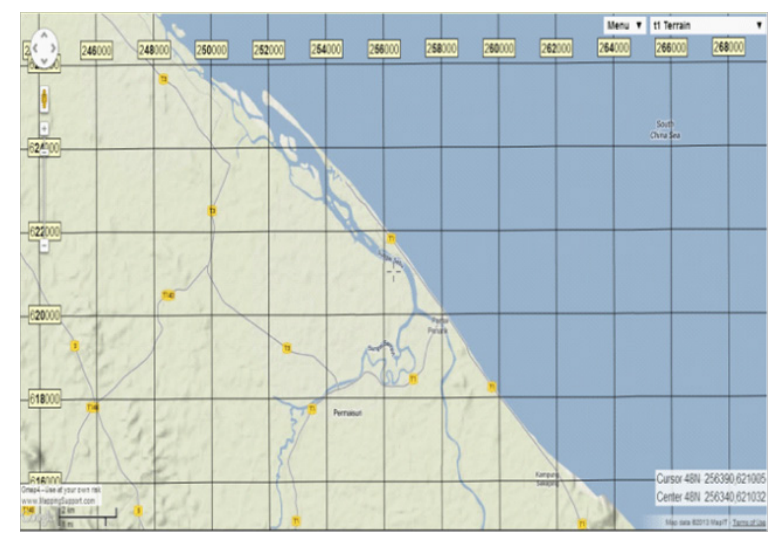

Figure I Setiu Wetland. 


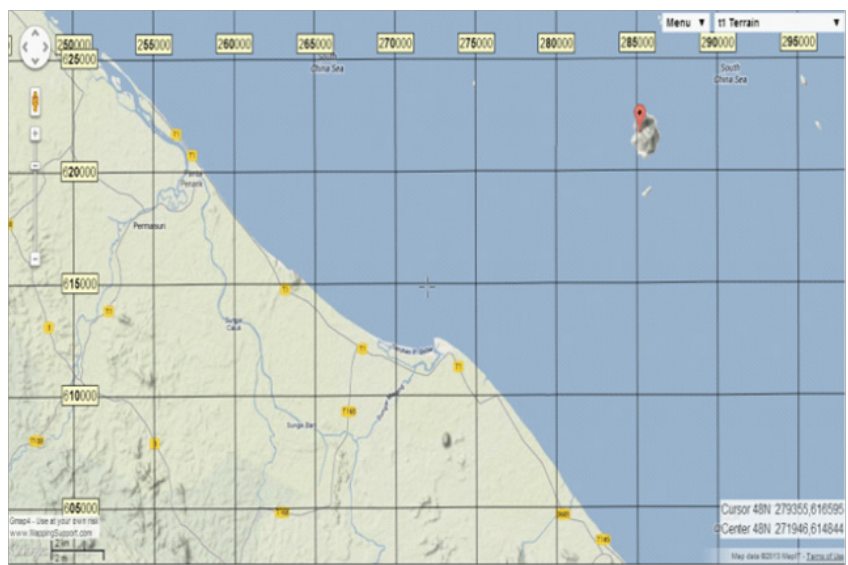

Figure 2 Bidong Island.

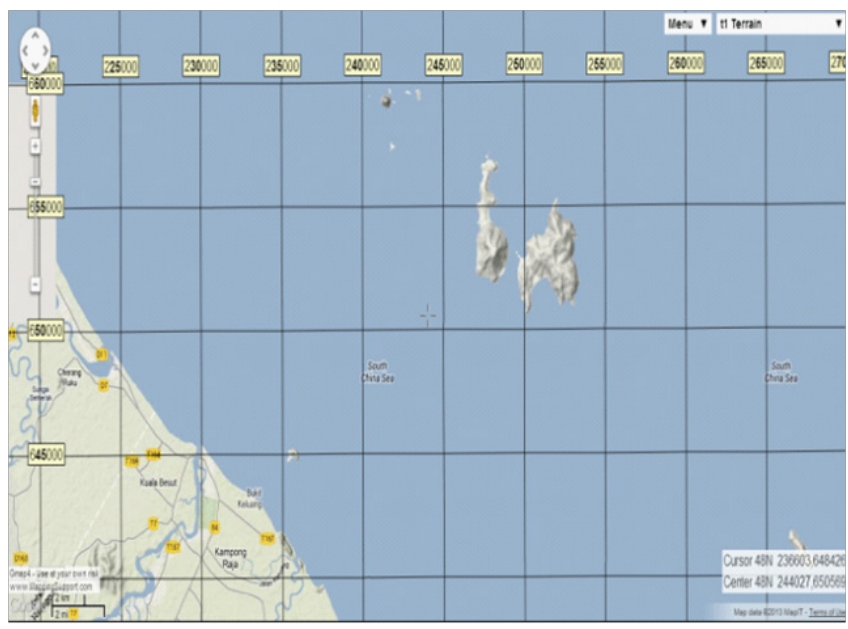

Figure 3 Perhentian Island.

\section{Samples Preservation}

Water sample are collect using vandorn water sampler and transferred to the bottle samples. Generally, at least one liter of water sample is needed. Sample volume is depending on the sampling location. The water samples are kept from heat and light to avoid pigment decomposition and bacteria infect. The location of each sampling sites are marks using GPS and the temperature of sea water is taken immediately to prevent surrounding disturbance. ${ }^{7}$ Hence, the water samples are place in an ice chest at temperature 1-4oC.

\section{Calorific Value and Power Efficiency}

Specific heat is the measure of kcals required to raise the temperature of $1 \mathrm{~kg}$ of oil by $10 \mathrm{oC}$. The unit of specific heat is $\mathrm{kcal} / \mathrm{kg}$. It fluctuates from 0.22 to 0.28 relying upon the oil specific gravity. The specific high temperature confirms what amount of steam or electrical vigor it takes to high temperature oil to a wanted temperature. ${ }^{8,9}$ Light oils have a low specific heat, in as much as heavier oils have a higher particular high temperature. Calorific value was evaluated using the following relations.

\section{Results}

\section{Physical Parameter Records}

The Figure 4 shows the latitude against temperature of sampling site whereas the latitude is decrease inversely proportional to the temperature at first point. Basically, the temperature is depending on the latitude because of water circulation patterns modify the direct effect of the amount of energy received from the sun.

The graph shows that not all of the temperature caused by latitude where at Setiu Wetland has highest temperature while their latitude is lower than Bidong Island. This is happening because the Setiu Wetland water has low salinity which is there are mixed of sea water and river.

The Table $1 \& 2$ showed the results from water analysis that conducted to analyze the nutrients of sea water in each sampling site which is Setiu Wetland, Bidong Island and Perhentian Island.

The values of total nitrogen at all sites are highest compare to others because there is more than $65 \%$ of nitrogen in sea water. Setiu Wetland has the highest values of nutrients caused the higher population of macro algae that need more nutrients to survive such as Ulva species.

There are four species of major species of macro algae found at sampling site based on matching of their physical and chemical characteristic such as temperature, salinity and nutrients contents in macro algae. The species in Setiu Wetland are Ulva lactuca and Enteromorpha intestinalis while in Bidong Island is Sargassum cristaefolium and in Perhentian Island are Sargassum cristaefolium and Glacilaria confervoides (Figure 5).

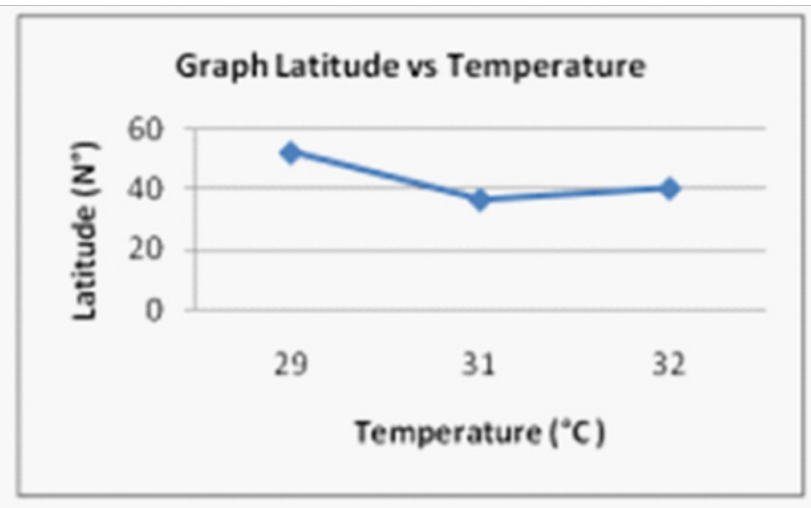

Figure 4 Graph Latitude against temperature.

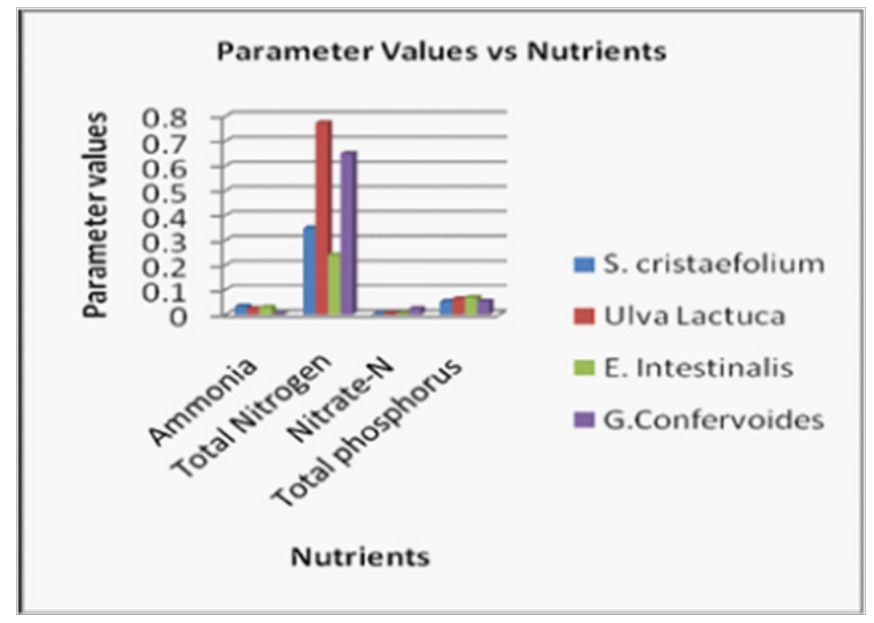

Figure 5 Graph parameter values against nutrients. 
Table I Experimental results

\begin{tabular}{llll}
\hline Sampling Site & & & \\
\hline Parameters & Bidong Island & Setiu Wetland & Perhentian Island \\
Temperature ${ }^{\circ} \mathrm{C}$ & 31 & 32 & 29 \\
Salinity $(\mathrm{ppm})$ & 32.34 & 24.1 & 35.13 \\
$\mathrm{pH}$ & 5.8 & 5 & 6 \\
Ammonia & 0.034 & 0.035 & 0.0665 \\
Total Nitrogen & 0.391 & 0.46 & 0.3265 \\
Nitrate-N & 0.002 & 0.002 & 0.003 \\
Total phosphorus & 0.045 & 0.045 & 0.031 \\
\hline
\end{tabular}

Table 2 Macro algae species with their parameters values

\begin{tabular}{lllll}
\hline Macro algae species & & & & \\
\hline Parameters & S. cristaefolium & Ulva Lactuca & E.Intestinalis & G.Confervoides \\
Temperature ${ }^{\circ} \mathrm{C}$ & $24-34$ & $22-34$ & $20-33$ & $31-34$ \\
Salinity (ppm) & $30-33$ & $19-22$ & $8.2-25$ & $15-32$ \\
$\mathrm{pH}$ & $4.0-6.0$ & $7.1-8.5$ & $6.9-9$ & $7.0-8.0$ \\
Ammonia & $0.029-0.039$ & $0.01-0.04$ & $0.02-0.04$ & $0.001-0.005$ \\
Total Nitrogen & $0.2-0.5$ & $0.65-0.9$ & $0.10-0.38$ & $0.5-0.8$ \\
Nitrate-N & $0.001-0.003$ & $0.002-0.008$ & $0.001-0.009$ & $0.001-0.004$ \\
Total phosphorus & $0.03-0.08$ & $0.04-0.09$ & $0.04-0.10$ & $0.02-0.09$ \\
\hline
\end{tabular}

\section{Conclusion}

Macro algae may found in many types of habitat in Malaysia such as Bidong Island, Redang Island, Perhentian Island and Setiu Wetland. The water analysis is used to identify the mineral contents in sea water in order to matching the species. In order to identify the market price, the costs of macro algae are calculated by drawing the cultivation system in 100000 meters for 10 blocks. The use of macro algae as the marine biomass energy sources has the potential to offset substantial use of fossil fuels. The net emission of carbon into the atmosphere can be reducing due to use the macro algae as biomass energy sources. This research estimates the carbon capture energy value from deployment aquaculture system for seaweed farming. Based on the market price of macro algae, the Ulva Lactuca and Sargassum cristaefolium are the lowest price compare to other species.

\section{Acknowledgments}

None.

\section{Conflicts of interest}

None.

\section{References}

1. Demirbas A, Arin G. Hydrogen from biomass via pyrolysis: relationships between yield of hydrogen and temperature. Energy Sources. 2004;26(11):1061-1069.
2. Chiang YM, WL Wang. Distribution of seaweed of the Hengchun Peninsula. In: Taiwan KH \& Chang (Eds.), Marine science. National Science Council Symposium Series 10. 1987;pp.71-87.

3. Asifa, Muneer. Energy Supply, its Demand and Security Issue for Developed and Emerging Economies, Renewable and Sustainable Energy Review. 2007;11(7):1388-1413.

4. Saxena, R, Adhikari D, Goyal H. Biomass-based energy fuel through biochemical routes: A review. Renewable and Sustainable Energy Reviews. 2007;13(1):167-178.

5. Indergaard M, Minsaas J. Animal and human nutrition. In: Guiry MD \& Blunden G (Eds.), Seaweed Resources in Europe: Uses and Potential. John Wiley \& Sons, Chichester. 1991;pp.21-64.

6. International Society for The Study of Harmful Algae $12^{\text {th }}$. International Conference on Harmful Algae, Copenhagen, Denmark. 2006.

7. Cecilia D, Nyberg. Introduced marine macro algae and habitat modifiers: their ecological role and significant attributes. Department of Marine Ecology, Goteborg University, Sweden. 2007.

8. Janet R. Stein. Handbook of Physiological Methods. Press Syndicate of the University of Cambridge. 1973.

9. Nisizawa K, Noda H, Kikuchi R, et al. the main seaweed foods in Japan. Hydrobiologia. 1987;151-152(1):5-29. 